\title{
Maubes Traditional House: the Cultural Legacy of Letmafo Society, North Central Timor District, East Nusa Tenggara
}

\author{
Mario Yosef Kabosu*; Hermanu Joebagio; Susanto Susanto \\ Department of History Education, Faculty of Teacher Training and Education, Sebelas Maret University, Indonesia \\ Email: mariomars32@gmail.com
}

http://dx.doi.org/10.18415/ijmmu.v5i4.266

\begin{abstract}
Maubes traditional house or also known as sonaf Maubes is the physical evidence of the existence, identity, and characteristic of Letmafo society. Maubes traditional house is designed not only as a physical construction,inhabitation but also has a socio-cultural meaning thatcovers any life dimensions.This research aims to elucidate the function as well as the wisdom values of Maubes traditional house. The descriptive qualitative was used as theresearch method. The data of research were the primary data that is interview and secondary data that is the data from observation and document analysis. The result of theresearch shows that Maubes traditional house has a function as a medium of unity, a place to deliberate for tribal members, a sacred place to make relation to the Supreme Being, and a storage room to keep the sacred objects of the predecessor. The values of Maubes traditional house are as follows: religious values, social values, educative values, and unity and brotherhood values.
\end{abstract}

Keywords: Local Culture; Maubes Traditional House; Letmafo Society;

\section{Introduction}

Indonesian society is plural society, which consists of tribes and cultures that spread in various regions in Indonesia. The tribes have a distinctive characteristic that is influenced by their world-view. The existence of Indonesian society, which lives in the cultural diversity, shows a high culture and civilization as the manifestation of responses toward nature and social challenges. Parsudi Suparlan, who was cited by Sumerta and Ariani (2014), explained that in the human life depends on their natural and physical environment and not solely manifested on a relationship in which the humans give influences and change the environments.

Refer to the Havilland's argumentation, who was cited by Sumerta and Ariani (2014), thateventhe elements of culture belong universally,nevertheless, in the level of subculture have differences or variations in form of thedistinctive norm and the pattern of habitual action that is followed by a group of people. One of theremarkable cultural legacies that still exist until nowadays is Maubes traditional house of Letmafo society in East Nusa Tenggara.This house is the manifestation of the local-traditional values that transmitting over ageneration and could become a medium to unite the tribes. 
The traditional house is a physical building that is built based on the customary law of tribes, in which it used as a reference in regulating all the tribes of members of the tribe. Tefa (2007) extensively describes indigenous houses as buildings that have special characteristics and used for shelter by a particular ethnic group. The traditional house is one of the highest cultural representations in a tribal community.

The growth and development of traditional houses arealong with the development of the tribes. It is because of the characteristics and ethnic identity of the supporting community is affected the dynamic of the traditional house. Halim (2011) argues that traditional houses as a material culture not only compose the completely material elements of the building. The architecture of the house also plays a role in the formation of social and symbolic spaces, in which, the "space" is reflecting the designer and the people who live in the house.

The presence of traditional house, both in the structure of the building or in the ritual event that is lived by the community, is an interesting phenomenon because in the ancient times until nowadays, specifically for traditional life, the presence of traditional houses determine the person fate. The traditional houses are also used as a place to carry out custom ceremonies and activities related to customs. This function is in line with Arifin`s (2010) finding that traditional houses reflect the cultural values that appear in the embodiment of the form, the structure, the layout, and the decoration.

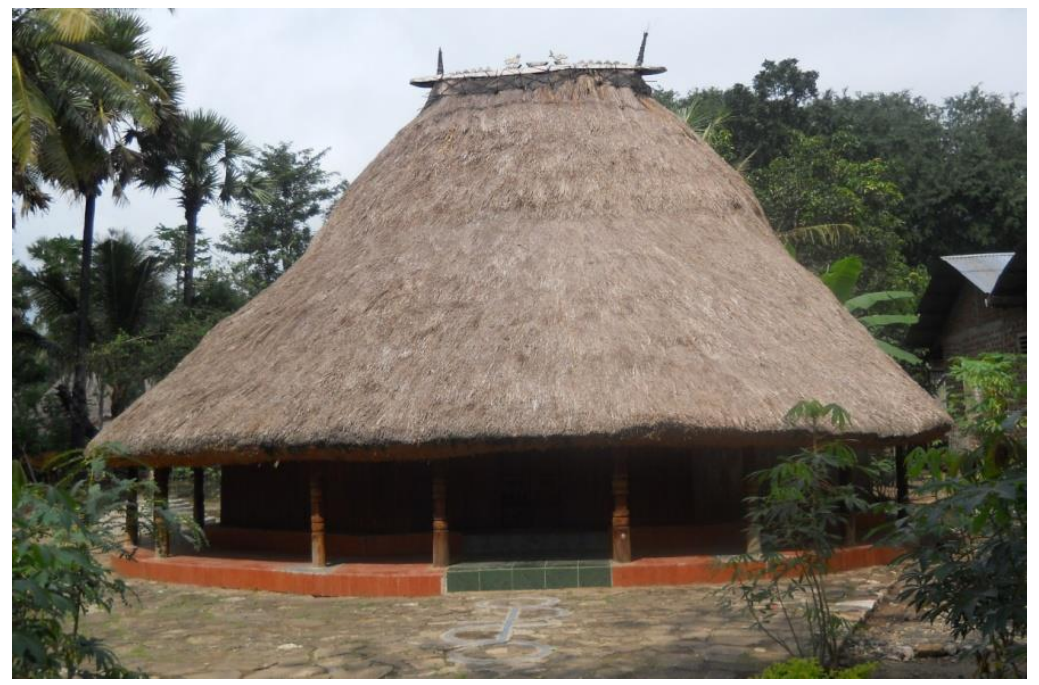

Fig. 1 The traditional house or Sonaf Maubes

Source: Authors`document

For the villagers of Letmafo, Maubes traditional house or better known as sonaf Maubes is a house that stores various historical relics and myth stories. The historical relics and myth stories believe by the villages could give a confidence and a belief of the owner about a something. As expressed by Ariani (2014) that human life depends on nature and vice versa. Thus, there is a very close relationship between God, man, and nature.

Agrest stated that the forms, the functions, and the symbols are interconnected devices and holistically form the overall shape of an architectural object. All of the cultures in the particular area could affect and shape the way in which architecture is built and developed (Halim., 2011). It is apparent in the architecture of sonaf Maubes that is built in a circle round shape, adapting to the universe and the 
sky surrounding the earth. For the villagers of Letmafo, the earth and sky were the sacred symbols of Uis Neno. Uis is representing the lord and then Neno is representing the sun. Therefore, the sonaf Maubes were made in a round shape and built with simplicity using traditional materials. Although the construction of the sonaf Maubes used these simple materials, the construction of the building of could survive for many years. As expressed by Wibowo (2014) that the buildings belonging to the vernacular architecture generally have strong characteristics with the cosmological orientation in the arrangement of the environment and the room because of the sacred and immanent orientations.

The uniqueness and simplicity of the form of sonaf Maubes have important meanings that are difficult to be told explicitly by the community. Although the sonaf is built based on the simplicity spirits, it building cannot be built arbitrarily or individually, but through a mature preparation and mutual assistance of the whole community. The existence of this traditional house not only become an emblazoned old house, but this house has a function and very rich in cultural values. In the authors' perspectives, the traditional house can be used as learning history resources.

The current development affects the changing in every aspect of life. This also affects the existing customary houses. However, the development does not always make a change, in which the authenticity of the Maubes traditional house still maintained. Therefore, it is very important for future generations to come and recognize the works of their ancestors who have been passed down through generations. In addition, many people do not know the history and even the function of the traditional house. Ironically, they not only forget about the history and functions of traditional houses but also the values contained in the traditional house. Therefore, to overcome this problem, it is very important to study the Maubes traditional house. This article is trying to describe the values of sonaf Maubes. The description focuses on the form and philosophical meaning of the constructional element of the house. Furthermore, the values of the sonaf Maubes are deriving from the implicit and explicit meaning of the house.

\section{Methodology}

The research location was in Letmafo Village, North Central Timor District, East Nusa Tenggara Province, Indonesia. The appropriate method to be used in this research is descriptive qualitative. Moleong (2011) stated that qualitative research is a research approach that stands on the natural setting, with the intention of interpreting the phenomenon by involving various triangulations.

The research type was conducted by descriptive research. The descriptive research consist of sections includes the subject portrait, the reconstruction of the dialogue, the description of the physical state, the structure of the place, and other relevant objects. Likewise, notes on specific events or persons, including who is involved in the manner in which, how the movements, as well as the behavior or attitudes (Sutopo., 2002).

\section{Findings and Discussion}

Said (2004) stated the definition of the traditional house as a building where the structure, manner of making, shape, function, and variety of decoration have their own characteristics passed down from over generations and used by the local people to carry out life activities. The Maubes traditional house as one of the hereditary heritage is the valuable legacy that should be preserved. 


\section{The function of Maubes Traditional House}

The Maubes traditional house is an interesting phenomenon. James HalpahMaupala, who is a traditional figure of Letmafo society, aged 81, explains that, physically, the building of Maubes traditional house in everyday life is very important for the existence of the community. The Maubes traditional house has several functions:

\section{A. The Medium of Unifying the Tribes}

As a medium of unifying the tribes, the Maubes traditional house established the good relationship among the relatives and other tribes. In the perspectives of religion, the traditional house is the immanent object that is established human relations with Uis Neno as the Supreme Being and the coming world. The most important this that is needed by the indigenous tribal house is unity.

The profane and immanent functions of Maubes traditional house is reflecting deep philosophical values that humans always need relationships with each other in life, both in the family or in wider community such as in the level of society and state. This kind of life could be manifested if there is a mutual acceptance, mutual respect, and mutual respect among members of the community. The villagers of Litmafo also experience it. The Sanak tribe always pays attention to help in the spirit of equality of fates and senses. Therefore, Sanak's traditional house is always used to reconcile and unite among member of tribes because for them unity must be upheld.

\section{B. Deliberation Place}

In the life of the Dawan tribe (Atoni Meto), the expression of a determination of Nekaf Mesma Ansaof Mese is always underlies their daily activities. This phrase becomes a motivation for doing the activity collectively. For the villagers of Letmafo, they feeling included in the unity of a society with similar traditions. Maubes traditional house is a place of deliberation because in this place the community underwent harmony among members of the tribe.

Not all topics are discussed in sonaf Maubes. The topics that are usually discussedrelate to the interests and responsibilities of all tribal members. For example, the problem of death (lais maten) as well as other matters relating to the interests of the tribe, and kinship dialogues so that all activities can run smoothly. 


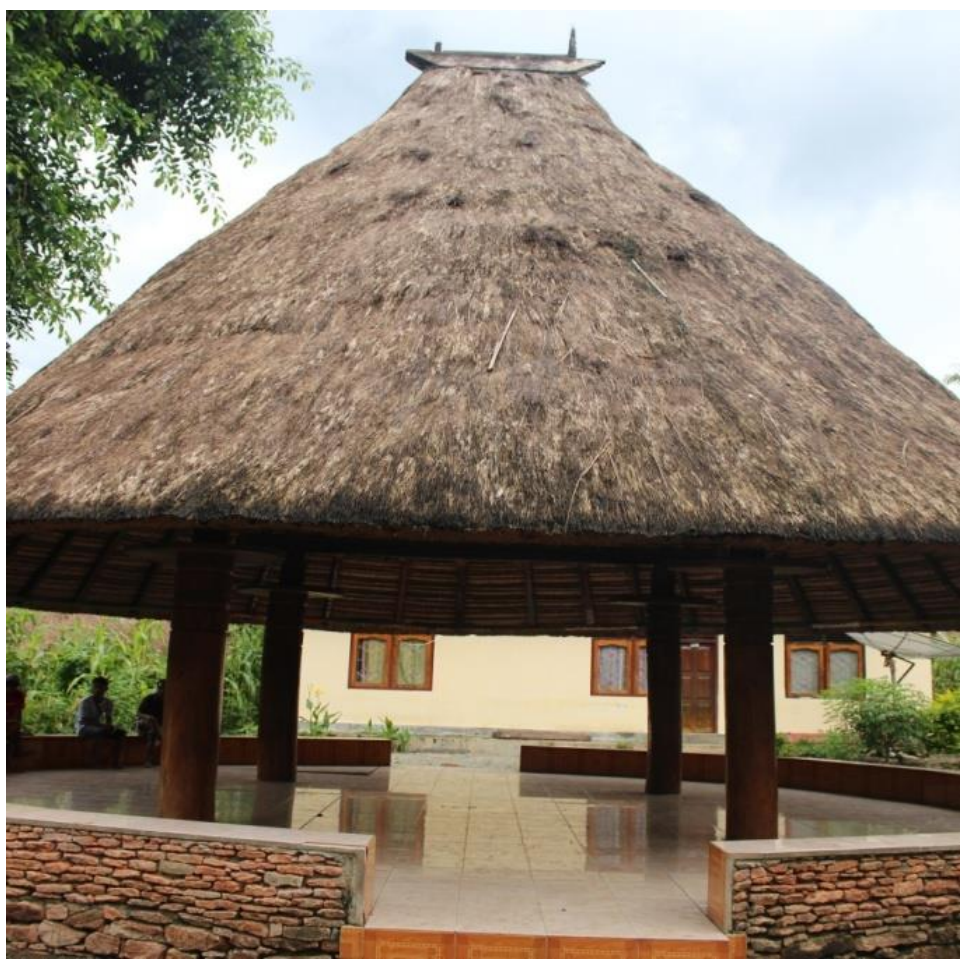

Fig. 2 A place for deliberation in sonaf Maubes

Source: Authors`documentation

\section{The Place to Communicate with the Supreme Being}

In the aspect of the human person, there is an awareness of the existence of an eternal essence that is sensed differently from the others. This is a particular sense that is different from the essence of nature and man. Inside of the human, there is a strong impulse to relate to the Supreme Being because, consciously, the human life is the gift of that immortal nature.

The villagers of Letmafo acknowledge the existence of a power that surpasses the human power that they call Uis Neno or the Supreme Being. This confession appears in the ceremony that is shown to honor the Supreme Being. In this ceremony, they maintain the harmonious relationship with the Uis Neno. 


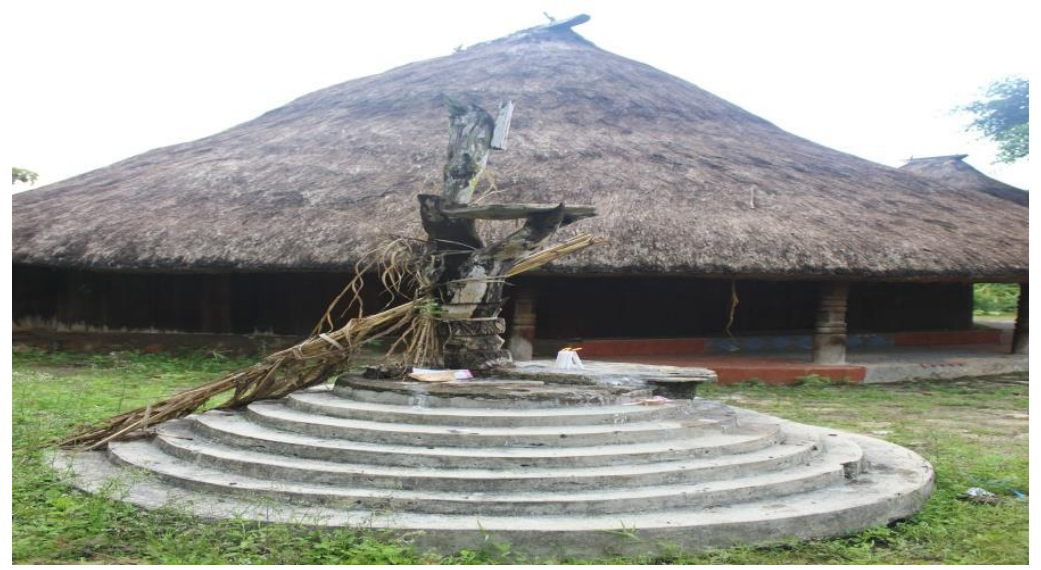

Fig. 3 The Tiang Agung or Great Pillar as the medium to relate to Uis Neno Source: Authors`documentation

\section{The Place to Store the Ancestral Heritage Objects}

Sonaf Maubes serves as a place for storage of ancestral heritage objects. In sonaf Maubes there are some ancient objects that have historical value. Those objects are the signs of the presence of ancestors. Although the other cultures entered and influenced the local culture or native culture, however, the tribal members are still captivated by the local culture.

The objects in the sonaf Maubes include gold, silver, council, weapons and bullets, custom fabrics, plates and spoons from the shell, spear, knife, flute, drums, mats, and buffalo horns.

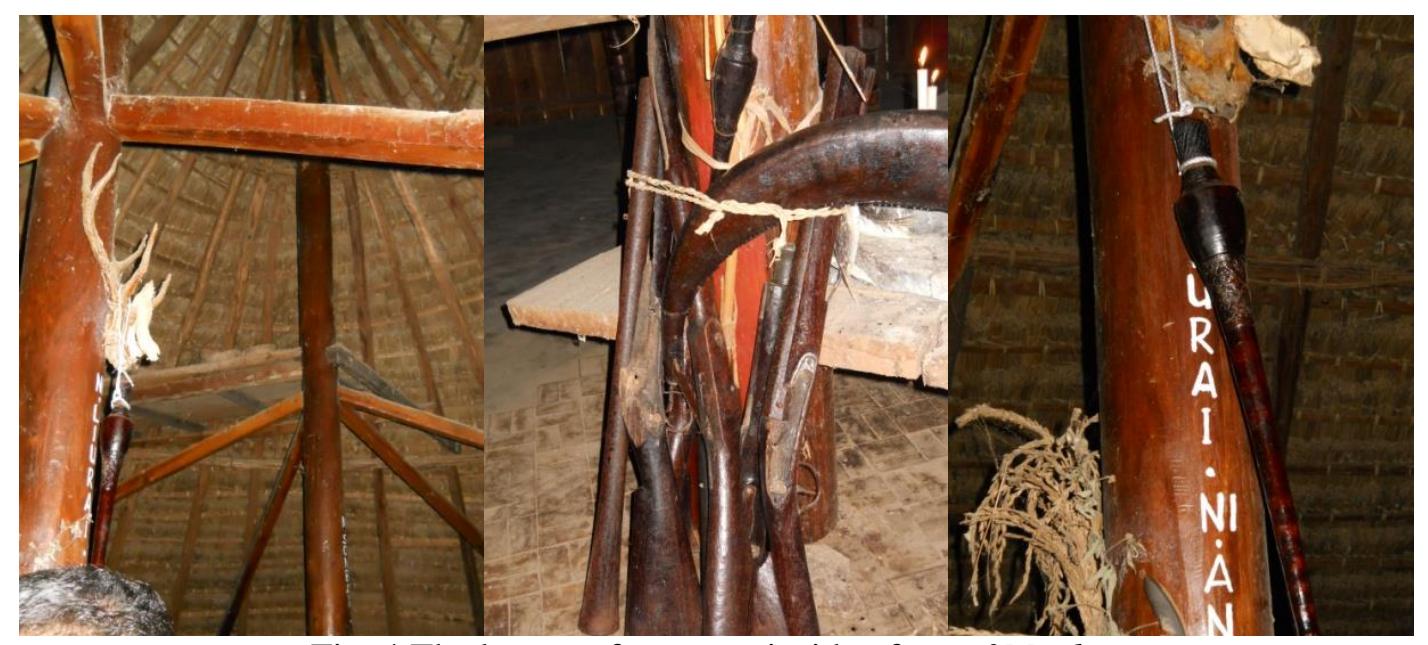

Fig. 4 The legacy of ancestor inside of sonaf Maubes

Source: Authors`documentation

\section{The Values of Sonaf Maubes}


Rokeach provides a definition of value as one of the basic elements in the formation of cultural orientation. The value involves a cultural concept that considers something as good or bad, right or wrong, fair or unjust, beautiful or ugly, clean or dirty, valuable or worthless, fit or not, and good or cruel. Although the values do not necessarily reflect behavior within a culture, it can explain the actions of the society. This is because value tends to be the basis for all decisions of the society make. The value is the basis for the society to judge their actions against others. The society considers the value as a hidden part of the culture (Liliweri., 2014).

According to the results of the interview with James HalpahMaupala, who is the traditional figure of Letmafo society, reveals the values contained in the sonaf Maubes are religious value, social value, educative value and the unity and brotherhood value.

\section{a) Religious Values}

The religious value of sonaf Maubes is as an intermediary of the prayers of tribes members to the Uis Neno. The sonaf Maubes is the residence of the deceased ancestors, and through the dead, all the requests from the member of the tribes can be conveyed to the Uis Neno.

\section{b) Social Values}

The social value is a value that lives inside of a society concerning the aspect of social life. In the life of the villagers of Letmafo, the social values are highly visible in the interactions that are built in their daily, whether among tribes members as well as with between the other tribes. The members of the tribes keep each other and foster the intimacy with one another. This value is still going on until now.

\section{c) Educative Values}

The value that is seen in all processes that have begun from finding the house pillars to be used as a Tiang Agung or great pillar of sonaf Maubes until the completion of the traditional house. The process to build the sonaf Maubes is actually intended to teach the next generation of Litmafo society that the making of sonaf Maubes is not only a matter of custom or tribe but also it contains knowledge and lesson for the next generation who will replace the elders in the future times.

\section{d) The Values of Unity and Brotherhood}

The values of unity and brotherhood of the sonaf Maubes appears in the building process of the house in which, it is always carried out jointly beginning with meetings with tribal leaders, the elders, and tribes members. The division of charge in every task is divided regularly, in order to avoid disputes and fights among tribes member. The fraternal brotherhood is not only between members of the tribe but with the other tribes that also respected secure and peaceful family relationship.

\section{Conclusion}


The traditional house is one of the elements of culture that exist and develops in a community. The traditional house also becomes the identity of a tribe. The villagers of Letmafo feel proud to the sonaf Maubes because it has uniqueness and peculiarities. This kind of uniqueness can be seen from the form, function, and the values of sonaf Maubes that have been maintained over generations. Inside of sonaf Maubes reflects the norms, rules, ideas, and customs that are imbued and practiced in everyday life. Refer to the importance of the function of sonaf Maubes, especially for the Letmafo society as the owner and its users as well as one of the cultural elements that had been inherited by the ancestors, it is necessary to get serious attention to the preservation of sonaf Maubes.

\section{References}

Ariani Ni Luh. (2014). Rumah Adat Suku Lamaholot Korke (Bentuk dan Fungsi). Jurnal Penelitian Sejarah dan Nilai Tradisional. 21(1): 47-56.

Arifin, Rosmiaty. (2010). PerubahanIdentitas Rumah Tradisional Kaili di Kota Palu. Jurnal Ruangan. 2(1): 20-30.

Halim. (2011). Perkembangan Rumah Tradisional Muna. Unity Jurnal Arsitektur. 1(2): 68-79.

Liliweri Alo. (2014). Pengantar Studi Kebudayaan. Bandung: Nusa Media.

Moleong, L. J. (2011). Metodologi Penelitian Kualitatif. Bandung: PT Remaja Rosdakarya.

Said, Abdul Aziz. (2004). Simbolisme Unsur Visual Rumah Tradisional Toraja.Yogyakarta.

Sumerta I Made dan Ariani Ni Luh. (2014). Kearifan Masyarakat Soe dalam Pelaksanaan Upacara Daur Hidup.Jurnal Penelitian Sejarah dan Nilai Tradisional. 21(1): 83-100.

Sutopo, H. B. (2002). Metodologi Penelitian Kualitatif. Surakarta: Sebelas Maret University Press.

Tefa, Sa’u A. (2007). Menghargai Tradisi Menghormati Karya Manusia. Kupang: Cipta Kasih.

Wibowo, Agus Budi. (2014). Konsep Privasi Pada Rumah Tinggal (Rumoh Aceh) di Gampong Lubok Sukon Kecamatan Ingin Jaya Kabupaten Aceh Besar Provinsi Aceh. Jurnal Penelitian Sejarah dan Nilai Tradisional. 21(1): 1-15.

\section{Copyrights}

Copyright for this article is retained by the author(s), with first publication rights granted to the journal.

This is an open-access article distributed under the terms and conditions of the Creative Commons Attribution license (http://creativecommons.org/licenses/by/4.0/). 